\title{
Formation of biogenic amines and bioactivities of Makgeolli under different fermentation conditions
}

\author{
Seung Mi Kang ${ }^{1}$, Seon Jeong Kim ${ }^{1}$, Keon Hee Ko ${ }^{1,2}$, Sanghae Nam ${ }^{1 *}$ \\ ${ }^{1}$ Division of Food Science, Gyeongnam National University of Science and Technology, Jinju 52725, Korea \\ ${ }^{2}$ Gyeongnam Oriental Medicinal Herb Institute, sancheong 52215, Korea
}

\section{발효조건에 따른 막걸리의 Biogenic Amines(BAs)의 생성과 생리활성}

\author{
강승미 ${ }^{1} \cdot$ 김선정 ${ }^{1} \cdot$ 고건희 ${ }^{1,2} \cdot$ 남상해 $^{1 *}$ \\ ${ }^{1}$ 경남과학기술대학교 식품과학과, ${ }^{2}$ 경남한방약초연구소
}

\begin{abstract}
Generation of biogenic amines (BAs) and physiological activities of Makgeolli, Korean rice wine, were investigated during fermentation under different temperatures $\left(20,25\right.$, and $\left.30^{\circ} \mathrm{C}\right)$ and time $(3,5$, and 7 days). The $\mathrm{pH}$ was 3.96 4.36 during fermentation and the acidity increased proportionally with temperature and time. Alcohol and total phenolic contents peaked on day 5 at 25 by $9.0 \sim 9.8 \%$ and $3.01 \pm 0.07 \mathrm{mg} / \mathrm{g}$, respectively. The organic acid mostly produced was lactic acid, which increased gradually with temperature and time. Formation of biogenic amines comprised of tryptamine and putrescine was observed during fermentation: $6.91,11.70$, and $15.63 \mathrm{mg} / \mathrm{mL}$ of tyramine on day 7 at 20, 25, and $30^{\circ} \mathrm{C}$, respectively. Antioxidant activities from DPPH and FRAP assay were high in the order of $25^{\circ} \mathrm{C}>\mathbf{2 0} 0^{\circ} \mathrm{C}>30^{\circ} \mathrm{C}$ while that from ABTS assay was high regardless of temperature. Processed at $1 \mathrm{mg} / \mathrm{mL}$ and $30^{\circ} \mathrm{C}$, the inhibitory effect on $\mathrm{a}$-amylase was $67.99 \pm 0.11,73.64 \pm 0.43$, and $75.51 \pm 0.26 \%$ on days 3,5 , and 7 , respectively, which increased proportionally with temperature and time. Inhibitory activity on lipid accumulation in 3T3-L1 adipocytes was the highest in Makgeolli fermented on day 5 at $25^{\circ} \mathrm{C}$. This study shows that fermentation at $25^{\circ} \mathrm{C}$ for 5 days yields Makgeolli of the best quality with high bioactivities but no biogenic amines.
\end{abstract}

Key words : biogenic amines, Makgeolli, fermentation, antioxidant, $a$-amylase, cell differentiation

\begin{abstract}
서 론
막걸리는 우리나라에서 역사가 가장 오래된 술인 탁주의 일종으로 찹쌀, 멥쌀 등의 전분질을 원료로 하고, 누룩을 첨가하여 병행 복발효시킨 술덧을 혼탁하게 제성한 우리 고유의 전통주이다(1). 최근 웰빙시대를 지나 힐링시대로 넘어오면서 주류시장 또한 소비동향이 변화하였다. 단순히 취하기 위해서가 아니라 다양한 음주문화를 즐기기 위해
\end{abstract}

*Corresponding author. E-mail : shnam@gntech.ac.kr Phone : 82-55-751-3274, Fax : 82-55-751-3279

Received 13 November 2015; Revised 2 March 2016; Accepted 8 March 2016.

Copyright (c) The Korean Society of Food Preservation. All rights reserved.
술을 찾는 사람이 많아져 알코올 함량이 낮은 술의 소비량 이 증가하였고, 건강과 더불어 술과 정서를 느끼는 문화가 확산되고 있다. 또한 막걸리의 다이어트 효능이 알려지면 서 여성들에게도 선호되고 있으며, 국내 뿐 아니라 외국에 서도 한류의 영향으로 한국 전통 음식과 더불어 관심이 높아지고 있다 $(2,3)$. 막걸리는 일반 술과는 달리 Vitamin $\mathrm{B}$ 군을 비롯하여 lysine, leucine, glutamic acid 및 proline 등의 아미노산과 glutathione 등 다양한 영양원이 풍부하게 함유되어 있으며, 갈증해소 및 신진대사를 원활히 하는 효 과가 있는 유기산의 함유량도 높은 것으로 알려져 있다(4). 또한 암세포의 성장을 억제하는 것으로 알려진 farnesol의 함유량이 맥주나 포도주의 10 25 배가량 높다는 연구결과 가 발표되었다(5). 생리할성에 대한 연구는 triglyceride와 
total cholesterol 등 혈중지질 감소 효과(6)에 대한 보고가 있으며, 최근에는 막걸리로부터 4-hydroxybenzaldehyde, 2-(4- hydroxylphenyl) ethanol(tyrosol), trans-ferulic acid, cis-ferulic acid 및 $1 \mathrm{H}$-indole-3-ethanol(tryptophol) 등의 항산 화 물질을 막걸리로부터 분리하여 발표하였다(7). 한편 막 걸리에 가공 저장 중 생성되는 biogenic amines(BAs)은 발효 식품이나 발효주에서 흔히 발견되는 생물학적 활성을 갖는 염기성 유기물질이며, 주로 식품 원재료의 효소에 의해 형 성되거나 미생물의 아미노산 탈탄산 반응에 의해서 생성된 다(8). BAs는 중추신경 전 달물질 또는 혈관계에 작용하는 등 다양한 생리활성을 나타내는 필수 성분이기도 하지만 다량을 섭취할 경우 독성을 나타내기도 한다(9). 막걸리에 는 많은 수의 유산균이 있고 발효 및 유통과정에서 BAs의 전구체가 될 수 있는 다량의 유리아미노산이 생성될 수 있다. 또한 막걸리는 1회 음용량이 많기 때문에 알코올 및 아세트알데히드의 존재에 의해 BAs의 독성이 증가할 수 있으므로 발효 또는 유통 중에서의 온도 관리 기준이 될 수 있는 지표가 필요한 실정이다(10). 식품에서의 아민 함량 은 $\mathrm{BAs}$ 를 생성하는 세균의 증식과 함께 증가하므로 BAs의 함량이 식품의 품질이나 열악한 제조과정의 지표로 이용되 는 것이 제안되고 있는 만큼 막걸리의 제조 시 온도와 시간 등의 발효조건에 따른 $\mathrm{BAs}$ 의 생성을 연구해야 할 필요가 있다. 보통 막걸리의 품질은 총산, 알코올 농도, 유기산, 풍미성분, 잔존 당 성분 등에 의하여 결정되며, 이것은 발효 및 저장 조건에 따라 크게 달라진다(11). 따라서 본 연구에 서는 발효 온도와 시간을 다르게 막걸리를 제조하여 각각의 품질특성과 BAs의 생성 및 항산화 및 항비만 등의 생리활 성을 비교 검토하였으며, 향후 위생적이고 품질이 우수한 막걸리 제조의 기초 자료가 되었으면 한다.

\section{재료 및 방법}

\section{실험재료 및 막걸리 제조}

막걸리 제조를 위해 쌀은 경남 산청군에서 2014년 생산 된 것을, 누룩은 국내 시판중인 산성누룩(산성마을 Co., Busan, Korea)과 효모(Lesaffre, Saint-Nazaire, France)를 각 각 구입하였다. 누룩 제조사에서 제시한 당화력은 300 400 $\mathrm{SP}$ 이었으며, 사용 전 낮에는 통풍이 잘되는 곳에서 햇볕을 쪼이고 밤에는 야외에 두는 법제과정을 2 일간 수행하였다. 막걸리의 제조는 다음과 같이 행하였다. 쌀을 10 회 세척하 여 2시간 침지시킨 후, 채반에 받쳐서 2시간 두었으며, 쌀 $500 \mathrm{~g}$ 에 대하여 누룩 $100 \mathrm{~g}$, 효모 $4 \mathrm{~g}$, 시판생수 $2 \mathrm{~L}$ 로 하여 $20,25,30^{\circ} \mathrm{C}$ 에서 각각 $3,5,7$ 일간 발효시켰다. 발효가 완료 된 막걸리는 즉시 $-20^{\circ} \mathrm{C}$ 에 보관하였으며, 이것을 발효조건 에 따른 biogenic amines(BAs) 및 유기산 분석 등을 위한 시료로 사용하였다.

\section{$\mathrm{pH}$ 및 산도}

발효 중인 막걸리의 $\mathrm{pH}$ 는 filter paper로 여과한 후, 직접 pH meter(Orion star A211, Thermo Sientific Co., Singapole) 로 측정하였고, 산도는 $1 \%$ phenolphtalein 지시약을 넣은 시료 $10 \mathrm{~mL}$ 를 $0.1 \mathrm{~N} \mathrm{NaOH}$ 로 적정하여 소비된 양을 lactic $\mathrm{acid}$ 의 함량(\%)으로 환산하였다(12).

\section{포도당 및 알코올 함량}

포도당은 디지털 혈당계(Accu-check active kit, Roche diagnostics $\mathrm{GmbH}, \mathrm{Germany)}$ 로 측정하였으며, 알코올 농도 는 국세청의 주류분석규정(13)에 따라 막걸리 $100 \mathrm{~mL}$ 를 증류한 후 포집된 유액은 주정계(NF35-515, Alla-france, France)를 이용하여 측정하였다.

\section{총 페놀 함량}

시료 중의 총 페놀 함량은 Folin-Denis법(14)으로 측정하 였다. 막걸리를 균일하게 섞은 후 filter paper로 여과한 것을 완전 농축하여 $1 \mathrm{mg} / \mathrm{mL}$ 가 되도록 $9 \%$ 에탄올에 녹여 시료 로 사용하였다. 시료 $0.5 \mathrm{~mL}$ 에 $2 \% \mathrm{Na}_{2} \mathrm{CO}_{3}$ 용액 $0.5 \mathrm{~mL}$ 을 첨가하여 3 분간 반응시킨 후 $2 \mathrm{~N}$ Folin-Ciocalteu's phenol $0.1 \mathrm{~mL}$ 를 혼합하여 $30^{\circ} \mathrm{C}$ incubator에서 60 분간 발색시켰다. 발색된 시료는 $5,000 \mathrm{rpm}$ 에서 10 분간 원심분리 한 후 microplate reader(EL800, BioTek, Winooski, PA, USA)를 이용하여 $750 \mathrm{~nm}$ 에서 흡광도를 측정하였다. 총 페놀 함량 은 gallic acid를 이용하여 작성한 표준곡선을 바탕으로 $\mathrm{mg}$ $\mathrm{GAE}$ (gallic acid equivalents)/g 으로 표시하였다. 각 실험은 3회 반복 수행하여 평균값으로 나타내었다.

\section{유기산 분석}

막걸리를 균일하게 혼합하여 filter paper로 여과한 후, $0.45 \mu \mathrm{m}$ membrane filter(SmartPor- ПSyringe filter, Woongki science, Seoul, Korea)로 다시 여과하였고, 시료의 유기산 함량은 HPLC(1260 Series, Agilent Co., Santa Clara, CA, USA)로 분석하였다. Analytical column은 Supelcogel C- $610 \mathrm{H}$ column $(7.8 \times 300 \mathrm{~mm}$, Supelco, Bellefonte, PA, USA), column 온도는 $30^{\circ} \mathrm{C}$, mobile phase는 $0.1 \%$ phosphoric acid를 사용하여 flow rate $0.5 \mathrm{~mL} / \mathrm{min}$, injection volume 10 $\mu \mathrm{L}$ 의 조건에서 detector는 UV $210 \mathrm{~nm}$ 에서 검출하였다(15). 유기산 표준물질은 막걸리와 같은 최종 알코올농도 $9 \%$ 로 보정한 용액에 녹여 HPLC로 분석하였으며 표준곡선을 작 성하여 각 유기산을 정량하였다.

\section{Biogenic Amines의 분석}

막걸리의 BAs 분석은 UPLC를 이용하여 tryptamine, phenylethylamine, putrescine, cadaverine, histamine, tyramine, spermidine 및 spermine 등 모두 8 종에 대하여 측정하였다. 시료는 $10 \mathrm{~mL}$ 의 막걸리에 $10 \mathrm{~mL}$ 의 $0.2 \mathrm{M} \mathrm{HCl}$ 과 내부표준 
물질로서 $1 \mathrm{mg}$ 의 1,7-diaminoheptane을 가하고 1 분간 섞어 준 후, 원심분리하여 상층액을 얻는 과정을 3 번 반복하고 그 상층액에 $0.1 \mathrm{M} \mathrm{HCl}$ 을 가하여 $50 \mathrm{~mL}$ 로 정용하였다. 시료에 $0.5 \mathrm{~mL}$ 포화 $\mathrm{NaHCO}_{3}$ 와 $1 \mathrm{~mL}$ 의 dansyl chloride(DCl) $\operatorname{reagent}(5 \mathrm{mg} / \mathrm{mL})$ 를 가하고 $40^{\circ} \mathrm{C}$ 에 60 분간 넣어둔 후, 200 $\mu \mathrm{L}$ 의 L-proline solution $(100 \mathrm{mg} / \mathrm{mL})$ 을 처리하여 1 분간 잘 섞어주고 실온의 어두운 곳에서 15 분간 반응시켰다(16). 각각의 유도체화 된 시료에 $1 \mathrm{~mL}$ 의 diethyl ether를 가하여 2 회 추출한 후, $\mathrm{N}_{2}$ gas로 건조시키고, acetonitrile $1 \mathrm{~mL}$ 로 다시 용해하여 UPLC로서 분석하였다. 기기는 UPLC (Acquity UPLC H-class system, Waters, Milford, MA, USA) 와 $\mathrm{C}_{18}$ reverse phase column $(4.6 \times 250 \mathrm{~mm}$, Shiseido, Japan)을 사용하였다. $\mathrm{DCl}$ 로 유도체화 된 $\mathrm{BAs}$ 검출을 위한 이동상으 로는 $0.1 \%$ formic acid 수용액(eluent $\mathrm{A}$ )과 $0.1 \%$ formic acid 가 함유된 acetonitrile 용액(eluent B)을 사용하였다. 이동상 의 flow rate는 $0.4 \mathrm{~mL} / \mathrm{min}$, solvent gradient program은 초기 에 eluent $\mathrm{A}$ 를 $45 \%$ 에서 5 분간 유지시킨 후, 7.5 분에 $35 \%$ 까 지, 10 분에 $20 \%$ 까지 농도를 낮추고 2.5 분간 유지하고, 다시 15 분에 $10 \%$ 까지 농도를 낮추어 1.5 분간 유지하며, 18.5 분 에 $45 \%$ 로 농도를 높여 2.5 분간 유지되도록 구성하였다. Column oven의 온도는 $40^{\circ} \mathrm{C}$, 검출기는 UVD $254 \mathrm{~nm}$ 에서 검출하였다. 8 가지 $\mathrm{BAs}$ 표준물질에서 검출된 peak의 retention time을 바탕으로 표준곡선을 확보한 후, 막걸리 시료에서의 BAs 생성 확인을 위한 기준으로 이용하였다.

\section{항산화 활성 측정}

DPPH free radical scavenging 활성

DPPH(2,2-diphenyl-1-picrylhydrazyl) free radical 소거활 성은 $\mathrm{Heo}$ 등의 방법(17)을 변형하여 실험하였다. 막걸리 여과 농축액을 농도별 $(1,000,500,250,125,62.5,31.25 \mu$ $\mathrm{g} / \mathrm{mL}$ )로 희석한 시료 $200 \mu \mathrm{L}$ 와 사용 직전에 만든 $0.2 \mathrm{mM}$ $\mathrm{DPPH}$ 를 $100 \mu \mathrm{L}$ 넣고 혼합하여 실온에서 30 분 동안 반응시 킨 후, microplate reader를 사용하여 $517 \mathrm{~nm}$ 에서 흡광도를 측정하였다. 각 시료 추출물의 DPPH radical 소거 활성은 실험구와 음성대조구의 흡광도를 구하여 아래와 같은 식으 로 계산하여 백분율(\%)로 표시하였다. 양성대조군으로 $\mathrm{BHA}$ 와 a-tocopherol의 활성과 비교하였으며 각 실험은 3회 반복하여 평균값으로 나타내었다.

\section{$\mathrm{DPPH}$ 라디칼 소거 활성(\%)=[1-(실험구의 흡광도/음성 대조구의 흡광도) $\times 100$}

$\mathrm{ABTs}^{+}$. cation radical scavenging 활성

$\mathrm{ABTS}$ radical을 이용한 항산화력 측정은 $\mathrm{ABTS}$ cation decolorization assay 방법(18)을 수정하여 실시하였다. 7 mM ABTS(2,2-azino-bis-(3-ethylbenzthiazoline-6-sulphonic acid diammonium salt)용액과 $2.45 \mathrm{mM}$ potassium persulfate
을 최종농도로 혼합하여 실온인 암소에서 24시간 두어 $\mathrm{ABTS}$ radical( $\mathrm{ABTs}^{+}$) 을 만들고, $\mathrm{ABTs}$ radical은 $732 \mathrm{~nm}$ 에 서 흡광도 값이 $0.7 \pm 0.02$ 가 되도록 PBS(phosphate buffer saline, $\mathrm{pH}$ 7.4) buffer로 희석하여 사용하였다. 96 well plate 에 희석한 ABTS 용액 $200 \mu \mathrm{L}$ 와 농도별 $(1,000,500,250$, $125,62.5,31.25 \mu \mathrm{g} / \mathrm{mL}$ )로 희석한 시료 $100 \mu \mathrm{L}$ 를 섞고 1 분 후 microplate reader를 사용하여 $732 \mathrm{~nm}$ 에서 흡광도를 측정하였다. 각 시료 추출물의 ABTs radical 소거 활성은 실험구와 음성대조구의 흡광도를 구하여 아래와 같은 식으 로 계산하여 백분율(\%)로 표시하였다. 각 실험은 3 회 반복 하여 평균값으로 나타내었다. 양성대조군으로 $\mathrm{BHA}$ 와 a -tocopherol의 소거활성과 비교하였다. 각 실험은 3 회 반복 하여 평균값으로 나타내었다.

\section{$\mathrm{ABTs}^{+}$-라디칼 소거 활성(\%)=[1-(실험구의 흡광도/음 성대조구의 흡광도) $\times 100$}

Ferric reducing antioxidant power(FRAP) 측정

FRAP 실험은 Benzie와 Strain의 방법(19)에 따라 측정하 였다. Reaction solution은 $300 \mathrm{mM}$ sodium acetate buffer $(\mathrm{pH}$ 3.6), $40 \mathrm{mM} \mathrm{HCl}$ 에 녹인 $10 \mathrm{mM}$ TPTZ[2,4,6-tri-(2-pyridyl1,3,5 -triazine)] 및 $20 \mathrm{mM}$ iron (III) chloride를 10:1:1로 실험 직전에 만들어 사용하였다. 반응액 $200 \mu \mathrm{L}$ 와 농도별로 희석 된 시료 $50 \mu \mathrm{L}$ 를 혼합하여 $37^{\circ} \mathrm{C}$ 에서 15 분간 반응시킨 후 microplate reader를 사용하여 $590 \mathrm{~nm}$ 에서 흡광도를 측정하 였다. 표준 곡선으로 $\mathrm{FeSO}_{4} \cdot 7 \mathrm{H}_{2} \mathrm{O}$ 를 사용하여 환원력을 계 산하였고 양성대조군으로 trolox의 환원력과 비교하였으며 각 실험은 3회 반복하여 평균값으로 나타내었다.

\section{항당뇨 (a-Amylase 저해) 활성}

a-Amylase는 소장 상피세포의 brush membrane에 존재하 는 효소로 탄수화물의 a-D-(1,4)-glucan 결합을 분해하는 효소이다(20). 따라서 소장의 a-amylase를 저해함으로써 포 도당의 흡수를 억제시킬 수 있어 a-amylase의 저해활성은 혈당수치 상승억제의 지표로 사용된다(21). 효소의 활성은 시간이 지날수록 감소하는 경향이 있어 실험 전 농도별 glucose와 효소의 무 샘플 실험으로 표준곡선을 그려 효소 의 활성 정도를 측정하여 실험 시 효소의 첨가량을 정한 후 시행하였다. a-Amylase 저해활성은 환원당 분석법(22) 을 응용하여 효소원으로 사람의 타액 amylase를 사용하고 기질로서 starch를 이용하여 효소활성을 측정하였다. 막걸 리 시료 $200 \mu \mathrm{L}, a$-amylase $(1$ unit $/ \mathrm{mL}) 0.5 \mathrm{~mL}, 0.1 \mathrm{M}$ potassium phosphate buffer(pH 6.8) $300 \mu \mathrm{L}$ 를 혼합하여 $37^{\circ} \mathrm{C}$ 에서 3 분간 pre-incubation한 후 $0.5 \%$ starch $0.5 \mathrm{~mL}$ 를 가하 여 $37^{\circ} \mathrm{C}$ 에서 20 분간 반응시켰다. 반응물에 $48 \mathrm{mM}$ DNS(3,5-dinitrosalicylic acid) 발색시약과 $30 \%$ sodium potassium tartarate가 포함된 $0.5 \mathrm{M} \mathrm{NaOH} 0.5 \mathrm{~mL}$ 를 넣고 
$85^{\circ} \mathrm{C}$ 에서 5 분간 끓여 발색 시키고 충분히 냉각한 후에 $5 \mathrm{~mL}$ 의 물을 가하고 잘 교반한 후 $200 \mu \mathrm{L}$ 씩 96 well plate에 옮겨 $540 \mathrm{~nm}$ 에서 흡광도를 측정하였다. 음성대조구는 시료 대신에 $9 \%$ ethanol $200 \mu \mathrm{L}$ 를 취하여 실험하였다. 이 때 활성 비교를 위해 제 2형 당뇨치료제에 쓰이는 acarbose를 사용 하였으며, 효소활성의 저해정도는 아래의 식에 의하여 산 출하였다. 각 실험은 3회 반복하여 평균값으로 나타내었다.

a-Amylase inhibition activity (\%)=[1-(시료처리구의 흡 광도/음성대조구 흡광도)]×100

\section{항비만 활성 측정}

3T3-L1 세포배양 및 분화

전지방세포인 3T3-L1 섬유아세포를 $10 \%$ FBS(fetal bovine serum, GIBCO Co., Gaithersburg, $\mathrm{MD}$, USA)와 $1 \%$ $\mathrm{PS}$ (penicillin-streptomycin, GIBCO Co.)가 첨가된 $\mathrm{DMEM}$ (Dulbecco's modified Eagle medium, GIBCO Co.)을 사용하 여 $37^{\circ} \mathrm{C}, 5 \% \mathrm{CO}_{2}$ incubator에서 배양하였다. 배양된 3T3-L1 지방세포가 $70 \%$ confluent 되었을 때 PBS(phosphate buffered saline)로 세척하고, $0.25 \%$ trypsin-EDTA 용액을 처리하여 $\mathrm{CO}_{2}$ incubator에서 3 분간 정치시킨 후 세포를 탈착시켜 $1,000 \mathrm{rpm}$ 에서 4 분간 원심분리하여 모은 세포를 배지로서 희석하여 $8 \times 10^{4} \mathrm{cell} / \mathrm{well}$ 의 농도로 분주하여 계대 배양하였다. 분화를 유도하기 위하여 6-well plate에 $0.8 \times 10^{5}$ cell/well로 분주하여 완전한 confluent 상태가 되었을 때, $10 \% \mathrm{FBS}$ 와 MDI 용액(0.5 mM 3-isobutyl-1-methylxanthine, $1 \mu \mathrm{M}$ dexamethasone, $10 \mu \mathrm{g} / \mathrm{mL}$ insulin)을 처리하여 분화를 유도하였다. 분화 유도 3 일 후 $10 \mathrm{\mu g} / \mathrm{mL}$ insulin, $10 \% \mathrm{FBS}$, $1 \% \mathrm{PS}$ 가 포함된 $\mathrm{DMEM}$ 으로 교환하였고 분화 유도 6일째 부터 매일 $10 \% \mathrm{FBS}$ 와 $1 \% \mathrm{PS}$ 가 포함된 $\mathrm{DMEM}$ 으로 교환하 여 분화시켰다.

\section{MTT assay}

막걸리의 지방세포에 대한 독성 여부를 알아보기 위하여 MTT[3-(4,5-methyl thiazol-2-yl)-2,5-diphenyl tetrazolium bromide] assay를 수행하였다(23). 96-well plate에 3T3-L1 preadipocyte를 $2 \times 10^{3}$ cells/well로 분주하였으며 총 용적을 $100 \mu \mathrm{L}$ 로 하여 $10 \% \mathrm{FBS}$ 가 포함된 $\mathrm{DMEM}$ 을 넣어주었다. 24 시간 배양한 후 배지를 제거하고 막걸리 추출물을 각각 의 농도별로 $(100,80,60,40,20,0 \mu \mathrm{g} / \mathrm{mL})$ 처리하여 24 시간 배양하였다. 그 후 배지를 제거하고 각 well에 $5 \mathrm{mg} / \mathrm{mL}$ MTT용액 $10 \mu \mathrm{L}$ 를 가하여 4 시간 배양하였다. 배양 종료 후 배양액과 MTT 용액을 PBS로 세척한 후 각 well에 200 $\mu \mathrm{L}$ 의 DMSO로서 생성된 formazan 결정을 용해시켜 microplate reader로서 $570 \mathrm{~nm}$ 에서 흡광도를 측정하였다.

\section{Oil red $O$ staining}

3T3-L1 전지방세포에 대한 막걸리 추출물의 분화억제
활성을 검토하기 위하여 Oil red O 염색을 실시하였다(24). $\mathrm{DMI}$ 용액과 막걸리 추출물에 의하여 분화 유도된 3T3-L1 세포의 배지를 제거한 후 PBS 용액으로 2 번 세척하고 PBS 용액을 완전히 제거하였다. $10 \%$ formalin $500 \mu \mathrm{L}$ 를 넣어 $4{ }^{\circ} \mathrm{C}$ 에서 5 분간 고정시킨 후 제거한 다음 다시 $10 \%$ formalin $1 \mathrm{~mL}$ 를 넣어 1 시간 고정하였다. Formalin을 제거하고 PBS 로 2번 세척한 후 Oil red O(Sigma Co., St. Louis, MO, USA) 용액을 가하여 1 시간동안 세포 내 생성된 지방구를 염색하 였다. 염색 후 PBS로 4 번 세척하여 과잉의 dye를 제거한 후, 현미경으로 막걸리 시료의 지방세포 분화억제 정도를 관찰하였다. 지방의 정량은 완전히 건조시킨 well에 $100 \%$ isopropanol을 $3 \mathrm{~mL}$ 첨가하여 Oil red O dye를 용출시켜 microplate reader로서 $500 \mathrm{~nm}$ 에서 흡광도를 측정하였다.

\section{통계 분석}

분석결과는 측정치의 평균과 표준편차로 나타내었고, 통 계 분석은 $3 \times 3$ 요인 실험 설계에 따라 $\mathrm{SAS}$ 통계 패키지 (SAS Institute Inc., Cary, NC, USA)의 General Linear Model(GLM) procedure를 이용하였고, 각 처리구간의 유의 성 검증은 분산분석을 실시 후, Duncan's multiple range test(Duncan, 1955)로, 5\% 수준(p<0.05)에서 실시하였다.

\section{결과 및 고찰}

\section{막걸리의 이화학적 특성 변화}

막걸리의 발효 중 이화학적 특성변화는 Table 1에 나타내 었다. $\mathrm{pH}$ 는 발효 초기인 3 일차에서는 $4.04 \pm 0.02 ~ 4.23 \pm 0.02$ 이었으며, 5 일차에서는 $4.18 \pm 0.02 \sim 4.36 \pm 0.01$ 로 온도에 비 례하여 약간 높아지는 경향이었다. 그러나 7일차에서는 2 $0^{\circ} \mathrm{C}$ 와 $25^{\circ} \mathrm{C}$ 에서 각각 $4.26 \pm 0.02$ 과 $4.34 \pm 0.01$ 로 약간 높아졌 으나, $30^{\circ} \mathrm{C}$ 에서는 $3.96 \pm 0.02$ 으로 오히려 약간 낮아지는 현 상을 보였다. 보통 막걸리의 발효 $\mathrm{pH}$ 는 4.0 4.6 정도로(25) 본 연구에서 제조한 막걸리도 이와 유사한 $\mathrm{pH}$ 범위를 나타 내었으며, 가장 높은 온도인 $30^{\circ} \mathrm{C}, 7$ 일차에서 $\mathrm{pH}$ 가 낮아진 것은 적정발효시기가 약간 경과하여 알코올이 초산으로 전환되었기 때문으로 사료된다. 총산은 $20^{\circ} \mathrm{C}$ 에서는 $0.159 \pm$ $0.003 \sim 0.202 \pm 0.006 \%, 25^{\circ} \mathrm{C}$ 에서는 $0.165 \pm 0.003 \sim 0.214 \pm 0.004 \%$, $30^{\circ} \mathrm{C}$ 에서는 $0.239 \pm 0.004 \sim 0.428 \pm 0.007 \%$ 로 발효기간과 온 도에 따라 점차 증가하였는데, 발효가 진행되면서 효모나 젖산균 등의 작용으로 인해 유기산이 생성되어 산도가 증가 된 것으로 판단되었다. 이러한 총산의 변화는 막걸리의 성 분변화를 알 수 있게 해주고 알코올의 생성과정에서 복합적 으로 생성되므로 막걸리의 발효 진행상황을 알 수 있는 지표성분이 된다(12). 막걸리의 $\mathrm{pH}$ 와 총산의 함량이 비례 적이지 않음을 알 수 있는데, 이는 So 등(26)의 보고에서와 같이 발효과정 중 단백질이 분해되어 펩티드와 아미노 
Table 1. Changes of $\mathrm{pH}$, acidity, glucose, alcohol and total phenolics content in Makgeolli according to different fermentation conditions

\begin{tabular}{|c|c|c|c|c|c|c|}
\hline \multicolumn{2}{|c|}{ Fermentation } & \multicolumn{5}{|c|}{ Changes of general components } \\
\hline Temperature $\left({ }^{\circ} \mathrm{C}\right)$ & $\begin{array}{l}\text { Periods } \\
\text { (day) }\end{array}$ & $\mathrm{pH}$ & Acidity $(\%)$ & Glucose content (mg/dL) & $\begin{array}{l}\text { Alcohol contents } \\
(\%)\end{array}$ & $\begin{array}{l}\text { Total phenolics } \\
\text { (mg GAE/g) }\end{array}$ \\
\hline \multirow{3}{*}{$20^{\circ} \mathrm{C}$} & 3 & $4.15 \pm 0.03^{\mathrm{bl})}$ & $0.159 \pm 0.003^{c}$ & $273 \pm 4.58^{\mathrm{a}}$ & $9.4 \pm 0.21^{b}$ & $2.80 \pm 0.05$ \\
\hline & 5 & $4.18 \pm 0.02^{\mathrm{b}}$ & $0.189 \pm 0.006^{b}$ & $163 \pm 1.53^{b}$ & $9.8 \pm 0.15^{\mathrm{a}}$ & $2.76 \pm 0.05$ \\
\hline & 7 & $4.26 \pm 0.02^{\mathrm{a}}$ & $0.202 \pm 0.006^{\mathrm{a}}$ & $85 \pm 3.51^{\mathrm{c}}$ & $8.8 \pm 0.12^{\mathrm{c}}$ & $2.82 \pm 0.02$ \\
\hline \multirow{3}{*}{$25^{\circ} \mathrm{C}$} & 3 & $4.23 \pm 0.02^{b}$ & $0.165 \pm 0.003^{c}$ & $219 \pm 4.93^{\mathrm{a}}$ & $9.6 \pm 0.06$ & $2.91 \pm 0.06$ \\
\hline & 5 & $4.25 \pm 0.02^{\mathrm{b}}$ & $0.178 \pm 0.002^{\mathrm{b}}$ & $130 \pm 2.08^{b}$ & $9.6 \pm 0.15$ & $3.01 \pm 0.07$ \\
\hline & 7 & $4.34 \pm 0.01^{\mathrm{a}}$ & $0.214 \pm 0.004^{\mathrm{a}}$ & $74 \pm 2.65^{\mathrm{c}}$ & $9.5 \pm 0.10$ & $3.00 \pm 0.16$ \\
\hline \multirow{3}{*}{$30^{\circ} \mathrm{C}$} & 3 & $4.04 \pm 0.02^{b}$ & $0.239 \pm 0.004^{b}$ & $67 \pm 1.15^{\mathrm{a}}$ & $8.4 \pm 0.17^{\mathrm{c}}$ & $2.85 \pm 0.14^{\mathrm{a}}$ \\
\hline & 5 & $4.36 \pm 0.01^{\mathrm{a}}$ & $0.221 \pm 0.002^{\mathrm{c}}$ & $31 \pm 2.00^{b}$ & $9.0 \pm 0.12^{\mathrm{a}}$ & $2.36 \pm 0.03^{b}$ \\
\hline & 7 & $3.96 \pm 0.02^{\mathrm{c}}$ & $0.428 \pm 0.007^{\mathrm{a}}$ & Lowc & $8.8 \pm 0.06^{b}$ & $2.34 \pm 0.02^{\mathrm{b}}$ \\
\hline
\end{tabular}

\footnotetext{
${ }^{1)}$ Values represent the mean \pm SD $(n=3)$. Means with different superscript with the column are significantly different $(\mathrm{p}<0.05)$ by Duncan's multiple range test.
}

산이 증가하여 완충능력을 높여주었기 때문이라고 판단하 였다. Jin 등(27)은 막걸리의 알코올은 술의 보존성이나 향 미에 영향을 주는 성분으로 함량이 다소 높아야 한다고 보고하고 있다. 본 연구에서는 $20^{\circ} \mathrm{C}$ 에서 발효 3,5 및 7 일차 에 각각 $9.4 \pm 0.21,9.8 \pm 0.15$ 및 $8.8 \pm 0.12 \%$ 로 7일차에 낮아졌 으나, $25^{\circ} \mathrm{C}$ 에서는 각각 $9.6 \pm 0.06,9.6 \pm 0.15$ 및 $9.5 \pm 0.10 \%$ 로 거의 변화가 없었다. 그러나 $30^{\circ} \mathrm{C}$ 에서는 각각 $8.4 \pm 0.17$, $9.0 \pm 0.12$ 및 $8.8 \pm 0.06 \%$ 로 7일차에서는 알코올 함량이 상당 히 감소하는 경향을 보여 적정 발효시기가 경과되고 있음을 알 수 있었다. 포도당 함량은 발효기간과 온도의 상승에 따라 점차 감소하였다. 포도당은 막걸리 발효 중 알코올 발효의 기질로 사용되어 함량이 감소한 것으로 판단된다 (28). Phenol 화합물은 phenolic hydroxyl기를 가진 식물체 유래의 대사산물로, 단백질 등의 거대분자들과 결합하려는 성질을 가지고 있기 때문에 항산화 효과 등의 생리활성을 가진다고 알려져 있고(29), 식품에서 phenol 화합물은 2차 대사산물로서 항산화 및 항균 등 다양한 생리활성을 나타내 며, 특히 항산화 활성과 양의 상관관계가 있어 간접적인
지표로 활용된다(30). 본 연구에서 막걸리의 phenol 화합물 의 함량을 gallic acid와 비교하여 측정하였다. $20^{\circ} \mathrm{C}$ 에서 $2.8 \pm 0.05 \sim 2.82 \pm 0.02 \mathrm{mg} \mathrm{GAE} / \mathrm{g}, 25^{\circ} \mathrm{C}$ 에서 $2.91 \pm 0.06 \sim 3.01 \pm$ $0.07 \mathrm{mg} \mathrm{GAE} / \mathrm{g}$ 으로 비교적 높은 함량을 나타내었다. $30^{\circ} \mathrm{C}$ 에서는 $2.85 \pm 0.14 ~ 2.34 \pm 0.02 \mathrm{mg} \mathrm{GAE} / \mathrm{g}$ 으로 발효기간이 경 과함에 따라 줄어들어 7 일차에 가장 낮았으며, $25^{\circ} \mathrm{C}$ 에서 5 일차의 막걸리에 총 페놀 화합물의 함량이 가장 높았다.

\section{유기산 함량}

막걸리의 발효온도 및 기간에 따른 유기산의 함량변화를 Table 2에 나타내었다. 모든 막걸리에서 citric acid, tartaric acid, lactic acid, acetic acid가 검출되었는데 이는 Choi 등 (31)의 연구결과와 유사하였다. 즉 citric acid는 온도가 높아 질수록 생성량은 늘어났으나 발효시간이 늘어남에 따라 감소하는 경향을 보였다. Tartaric acid는 $20^{\circ} \mathrm{C}, 3$ 일차에서 가장 높은 함량을 보였고 발효 온도와 기간의 증가에 따라 $0.45 \sim 0.12,0.40 \sim 0.10,0.17 \sim 0.09 \mathrm{mg} / \mathrm{mL}$ 로 점차 감소하였다. 알코올과 알데히드 산화에 의해 생성되는(32) acetic acid는

Table 2. Production of organic acids in Makgeolli according to different fermentation conditions

\begin{tabular}{ccccccc}
\hline \multicolumn{2}{c}{ Fermentation } & \multicolumn{5}{c}{ Organic acid contents $(\mathrm{mg} / \mathrm{mL})$} \\
\hline Temperature. $\left({ }^{\circ} \mathrm{C}\right)$ & Periods (day) & Citric acid & Tartaric acid & Lactic acid & Acetic acid & Total \\
\hline \multirow{2}{*}{$20^{\circ} \mathrm{C}$} & 3 & 0.29 & 0.45 & 1.03 & 0.03 & 1.8 \\
& 5 & 0.28 & 0.36 & 1.05 & 0.06 & 1.75 \\
& 7 & 0.24 & 0.12 & 1.30 & 0.10 & 1.76 \\
\hline \multirow{2}{*}{$25^{\circ} \mathrm{C}$} & 3 & 0.42 & 0.40 & 1.02 & 0.06 & 1.9 \\
& 5 & 0.40 & 0.24 & 1.17 & 0.05 & 1.86 \\
& 7 & 0.18 & 0.10 & 1.71 & 0.08 & 2.07 \\
\hline & 3 & 0.48 & 0.17 & 2.03 & 0.04 & 2.72 \\
& 5 & 0.39 & 0.13 & 2.57 & 0.10 & 3.19 \\
\hline
\end{tabular}


발효기간과 온도에 따라 생성량이 소폭 증가하였으나 $0.03 \sim 0.15 \mathrm{mg} / \mathrm{mL}$ 로 다른 유기산에 비하여 미량으로 검출되 었다. Lactic acid는 검출된 유기산들 중 함유량이 1.03 1.30, $1.02 \sim 1.71,2.03 \sim 4.13 \mathrm{mg} / \mathrm{mL}$ 로 가장 높게 나타났다. 즉 lactic acid와 acetic acid는 발효온도와 기간이 증가할수록 생성량이 많아져서 자극적인 신맛이 증가하고, citric acid 및 tartaric acid는 발효기간이 경과할수록 줄어들어 감칠맛 이 나는 상큼한 신맛과 떫은맛은 약간 감소하는 것을 알 수 있었다.

\section{Biogenic amine 함량}

검출된 $\mathrm{BAs}$ 는 대부분의 실험군에서 가공 저장 중 생성되 는 tryptamine과 미량의 putrecine이 $8.23 \sim 11.22 \mathrm{mg} / \mathrm{L}$ 및 $2.25 ~ 3.21 \mathrm{mg} / \mathrm{L}$ 검출되어 발효과정 중에 큰 변화가 없었으 나, tyramine은 발효 7일째에만 각각 6.91, 11.70 및 15.63 $\mathrm{mg} / \mathrm{L}$ 검출되었다. 이는 Jeong 등(33)에서 putrescine은 발효 초기인 1 일부터 검출되었으며, tyramine은 7일째에서만 검 출되었다는 보고와도 일치한다. 총 BAs 함량은 발효 5 일째 까지는 $11.42 \sim 13.39 \mathrm{mg} / \mathrm{mL}$ 로서 큰 변화가 없이 발효기간 이 길어질수록 조금씩 증가하였으나, 7일째에는 17.66 $25.72 \mathrm{mg} / \mathrm{mL}$ 로 급격히 증가하였다. 이러한 결과로 막걸리 의 BAs는 저장 유통 중에 생성될 뿐만 아니라 발효 중에도 생성된다는 것을 알 수 있다. BAs중 tyramine과 phenylethylamine은 혈관 수축인자들을 분비해서 고혈압을 일으킬 수 있으며(34), histamine은 식중독의 원인이 되며, 알레르기성 과민반응을 일으키므로 독일, 벨기에 및 프랑 스 등에서는 와인 등의 발효주에서 검출되는 histamine의 허용량을 각각 2, 5 6 및 $10 \mathrm{mg} / \mathrm{L}$ 로 정하고 있다(10). 본 실험에서는 모든 실험군에서 histamine이 검출되지 않았다. 그러나 putrescine, cadaverine, spermidine 등은 free radical 소거능이 있고, tyramine은 높은 항산화 효과를 갖는다는

Table 3. Formation of BAs in Makgeolli according to different fermentation conditions

\begin{tabular}{cccccc}
\hline \multicolumn{3}{c}{ Fermentation } & \multicolumn{5}{c}{ Biogenic amines (BAs) content $(\mathrm{mg} / \mathrm{L})$} \\
\hline $\begin{array}{c}\text { Temperature. } \\
\left({ }^{\circ} \mathrm{C}\right)\end{array}$ & $\begin{array}{c}\text { Periods } \\
(\text { day })\end{array}$ & Tryptamine & Putrescine & Tyramine & Total \\
\hline \multirow{2}{*}{$20^{\circ} \mathrm{C}$} & 3 & 10.32 & 2.29 & $-{ }^{1)}$ & 12.61 \\
& 5 & 10.50 & 2.35 & - & 12.85 \\
& 7 & 8.23 & 2.52 & 6.91 & 17.66 \\
\hline \multirow{2}{*}{$25^{\circ} \mathrm{C}$} & 3 & 9.17 & 2.25 & - & 11.42 \\
& 5 & 10.72 & 2.67 & - & 13.39 \\
& 7 & 11.22 & 2.80 & 11.70 & 25.72 \\
\hline $30{ }^{\circ} \mathrm{C}$ & 3 & 10.21 & 2.85 & - & 13.06 \\
& 5 & 9.85 & 3.03 & - & 12.88 \\
& 7 & 8.84 & 3.21 & 15.63 & 27.68 \\
\hline
\end{tabular}

${ }^{1)}$ Not detected.
보고가 있다(35). 그러나 다량 섭취할 경우 안정성 측면에서 $\mathrm{BAs}$ 는 주요 관리 요인이며, 주로 미생물의 아미노산 탈탄 산 반응에 의해 생성되기 때문에 다수의 유산균이 살아있는 상태로 저장, 유통되는 막걸리는 BAs의 생성이 시작되는 발효단계에서부터 그 생성을 저하시키기 위한 노력이 필요 하다. 이는 막걸리의 대중화와 세계화에 힘입어 소비가 증 가되고 있는 현재 막걸리의 품질을 한층 끌어올리는 의미 있는 연구가 될 것이다. 이와 같이 막걸리의 성분변화를 볼 때, 맛에 관여하는 $\mathrm{pH}$ 와 총산, 알코올 및 유기산의 함량 변화와 항산화효과의 지표로 볼 수 있는 총 페놀화합물의 함량, 그리고 식품의 품질이나 열악한 제조과정의 지표로 이용되기도 하는 BAs의 생성량 등을 종합해 보면, 막걸리 의 최적 발효조건은 $25^{\circ} \mathrm{C}$ 에서 5 일간 발효하였을 때가 가장 품질이 우수한 막걸리를 제조할 수 있을 것으로 판단되 었다.

\section{항산화활성}

막걸리의 항산화활성을 알아보기 위하여 농도별로 $\mathrm{DPPH}, \mathrm{ABTS}$ 및 FRAP 활성을 측정하였다(Table 4). DPPH assay에 의한 항산화활성은 $1 \mathrm{mg} / \mathrm{mL}$ 처리하였을 때, $20^{\circ} \mathrm{C}$ 와 $25^{\circ} \mathrm{C}$ 에서는 발효기간에 따라 $46.39 \pm 1.47 \sim 51.26 \pm 0.77 \%$ 로 서 큰 변화가 없었으나, $30^{\circ} \mathrm{C}$ 에서는 발효 3,5 및 7 일째에 각각 $47.92 \pm 2.42,36.48 \pm 1.85$ 및 $38.36 \pm 2.75$ 로 발효기간이 길어질수록 크게 감소하였다. DPPH는 분자 내에 안정한 radical을 함유하지만 항산화 활성이 있는 물질과 반응하면 radical이 소거되는 원리를 이용한 시료의 전자 공여능력을 측정하는 방법이다(36). Blois(37) 및 Jeong 등(38)의 보고에 서 수소전자 공여능력은 인체 내의 지질, 단백질과 결합하 여 질병 및 노화를 일으키는 free radical의 반응을 정지시키 는 것으로 phenolics 및 flavonoids 함량과 항산화 활성 간에 양의 상관관계가 있는 것으로 알려져 있는데(30), 본 실험에 서도 DPPH radical 소거능이 페놀함량에 비례적으로 높아 져 결과가 일치하였다. ABTS assay에 의한 항산화활성은 $1 \mathrm{mg} / \mathrm{mL}$ 처리하였을 때, 본 실험에서 실시한 모든 발효온도 에서 86.46 $\pm 0.35 \sim 87.79 \pm 0.61 \%$ 를 나타내었다. 이는 동일 농 도에서의 BHA와 a-tocopherol과 유사할 정도의 높은 활성 이었다. 대부분의 추출물에서는 본 실험에서와 같이 DPPH radical 소거능에 비해 ABTS radical 소거능이 높게 나타나 는데, 이는 radical의 입체특이성, 추출물의 용해도 등의 차 이에서 기인한다(39)고 알려져 있다. FRAP assay는 낮은 $\mathrm{pH}$ 에서 colored ferrous-TPTZ 복합체에 의해 ferric ion이 ferrous로 전환되어지는 과정을 분석하여 항산화력을 측정 하는 것으로 대부분의 항산화제가 환원력을 가지고 있다는 점에 착안하여 고안되어진 방법이다(40). FRAP assay에 의 한 항산화활성은 $1 \mathrm{mg} / \mathrm{mL}$ 처리하였을 때, $20^{\circ} \mathrm{C}$ 에서는 발효

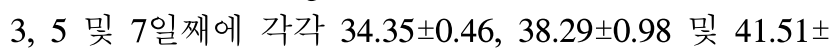
$0.59 \%$ 를 나타내어 발효기간에 따라 조금씩 증가하였다. 
Table 4. Antioxidant activities of Makgeolli according to different fermentation temperature and periods

\begin{tabular}{|c|c|c|c|c|c|c|c|c|c|c|c|}
\hline \multirow{3}{*}{$\begin{array}{c}\text { Antioxidant } \\
\text { test }\end{array}$} & \multirow{3}{*}{$\begin{array}{c}\text { Treated } \\
\text { conc. } \\
(\mu \mathrm{g} / \mathrm{mL})\end{array}$} & \multicolumn{10}{|c|}{ Antioxidant activities (\%) } \\
\hline & & \multicolumn{3}{|c|}{$20^{\circ} \mathrm{C}$} & \multicolumn{3}{|c|}{$25^{\circ} \mathrm{C}$} & \multicolumn{3}{|c|}{$30^{\circ} \mathrm{C}$} & Positive controls \\
\hline & & 3 days & 5 days & 7 days & 3 days & 5 days & 7 days & 3 days & 5 days & 7 days & a-Tocophero \\
\hline \multirow{6}{*}{ DPPH } & 1,000 & $46.39 \pm 1.47^{(1)}$ & $48.74 \pm 0.57^{f}$ & $48.39 \pm 0.54^{\text {ef }}$ & $51.26 \pm 0.77^{\mathrm{de}}$ & $48.15 \pm 0.73^{\text {ef }}$ & $47.92 \pm 0.47^{\mathrm{ef}}$ & $47.92 \pm 2.42^{\text {ef }}$ & $36.48 \pm 1.85^{\text {gh }}$ & $38.36 \pm 2.75^{g}$ & $91.57 \pm 0.09^{a} \quad 91.31 \pm 0.09^{a}$ \\
\hline & 500 & $28.97 \pm 0.51^{\mathrm{jk}}$ & $33.37 \pm 0.37^{\mathrm{hi}}$ & $30.79 \pm 1.30^{\mathrm{ij}}$ & $35.31 \pm 0.20^{\text {gh }}$ & $29.15 \pm 1.42^{\mathrm{jk}}$ & $33.43 \pm 1.63^{\mathrm{hi}}$ & $30.38 \pm 0.90^{\mathrm{ij}}$ & $21.99 \pm 0.41^{\mathrm{m}}$ & $27.68 \pm 1.15^{\mathrm{jd}}$ & $91.26 \pm 0.18^{\mathrm{a}} \quad 91.52 \pm 0.16^{\mathrm{a}}$ \\
\hline & 250 & $18.24 \pm 1.41^{\mathrm{no}}$ & $20.18 \pm 0.37^{\mathrm{mn}}$ & $18.06 \pm 0.71^{\text {no }}$ & $22.17 \pm 0.54^{\mathrm{m}}$ & $18.71 \pm 3.20^{\mathrm{mno}}$ & $19.65 \pm 1.73^{\mathrm{mn}}$ & $18.12 \pm 1.50^{\mathrm{no}}$ & $12.38 \pm 0.30^{\mathrm{qrs}}$ & $25.92 \pm 0.77^{\mathrm{kd}}$ & $89.79 \pm 0.16^{\mathrm{a}} \quad 91.20 \pm 0.16^{\mathrm{a}}$ \\
\hline & 125 & $18.71 \pm 1.22^{\mathrm{mmo}}$ & $15.31 \pm 2.80^{\mathrm{opq}}$ & $14.02 \pm 1.85^{\mathrm{pqr}}$ & $18.36 \pm 5.70^{\mathrm{no}}$ & $15.13 \pm 1.86^{\circ \mathrm{pq}}$ & $18.65 \pm 2.86^{\mathrm{mmo}}$ & $17.18 \pm 0.71^{\text {nop }}$ & $17.24 \pm 1.80^{\text {nop }}$ & $19.94 \pm 3.51^{\mathrm{mn}}$ & $77.54 \pm 0.82^{b} \quad 56.34 \pm 0.72^{c}$ \\
\hline & 62.5 & $10.26 \pm 2.60^{\text {stu }}$ & $9.91 \pm 1.23^{\text {stu }}$ & $8.62 \pm 0.27^{\text {tur }}$ & $10.85 \pm 2.24^{\text {st }}$ & $9.62 \pm 2.10^{\text {sur }}$ & $9.21 \pm 1.06^{\text {stur }}$ & $7.33 \pm 1.63^{\text {tuv }}$ & $6.10 \pm 0.57^{\mathrm{ww}}$ & $13.90 \pm 4.17^{\mathrm{pqr}}$ & $53.93 \pm 0.87^{\text {cd }} \quad 25.45 \pm 1.321$ \\
\hline & 31.25 & $10.03 \pm 1.03^{\text {stu }}$ & $7.92 \pm 1.67^{\text {tws }}$ & $6.63 \pm 1.48^{\mathrm{uWw}}$ & $9.79 \pm 4.22^{\text {stuv }}$ & $9.15 \pm 2.90^{\text {stur }}$ & $8.45 \pm 1.86^{\text {thv }}$ & $9.27 \pm .5 .41^{\text {stur }}$ & $6.51 \pm 3.37^{\mathrm{uww}}$ & $3.28 \pm 1.47^{\mathrm{w}}$ & $30.26 \pm 1.29^{\mathrm{ij}} \quad 12.83 \pm 1.25^{\mathrm{qr}}$ \\
\hline \multirow{6}{*}{ ABTS } & 1,000 & $86.46 \pm 0.35^{\mathrm{bc}}$ & $87.44 \pm 0.35^{b}$ & $87.77 \pm 0.51^{\mathrm{ab}}$ & $87.61 \pm 0.25^{\mathrm{ab}}$ & $87.68 \pm 0.59^{\mathrm{ab}}$ & $87.67 \pm 0.49^{\mathrm{ab}}$ & $87.79 \pm 0.61^{\mathrm{ab}}$ & $86.63 \pm 0.74^{b c}$ & $86.30 \pm 0.40^{\mathrm{bc}}$ & $89.44 \pm 0.39^{\mathrm{a}} \quad 84.84 \pm 0.15^{\mathrm{cc}}$ \\
\hline & 500 & $74.08 \pm 0.78^{g}$ & $79.79 \pm 0.64^{\mathrm{f}}$ & $80.03 \pm 0.44^{\mathrm{f}}$ & $83.41 \pm 0.81^{\text {de }}$ & $79.17 \pm 0.35^{f}$ & $82.24 \pm 0.90^{\mathrm{e}}$ & $81.84 \pm 0.86^{\circ}$ & $79.07 \pm 0.87^{\mathrm{f}}$ & $79.23 \pm 0.48^{\mathrm{f}}$ & $88.07 \pm 0.39^{\mathrm{ab}} \quad 81.77 \pm 0.39^{\mathrm{e}}$ \\
\hline & 250 & $56.67 \pm 0.67^{\mathrm{n}}$ & $63.74 \pm 0.70^{\mathrm{m}}$ & $65.85 \pm 0.81^{\mathrm{kl}}$ & $69.51 \pm 0.51^{\mathrm{i}}$ & $64.42 \pm 0.86^{\mathrm{mm}}$ & $68.76 \pm 0.77^{\mathrm{ji}}$ & $67.85 \pm 1.06^{\mathrm{ij}}$ & $68.31 \pm 0.95^{\mathrm{ij}}$ & $66.92 \pm 0.16^{\mathrm{k}}$ & $87.22 \pm 0.26^{b} \quad 79.56 \pm 0.26^{f}$ \\
\hline & 125 & $37.80 \pm 0.36^{\mathrm{u}}$ & $45.02 \pm 0.53^{\mathrm{t}}$ & $48.73 \pm 1.33^{\mathrm{IS}}$ & $49.91 \pm 0.93^{9 r}$ & $47.47 \pm 1.41^{\mathrm{s}}$ & $51.78 \pm 0.59^{o p}$ & $53.22 \pm 5.22^{\circ}$ & $50.35 \pm 1.48^{\mathrm{pqr}}$ & $51.36 \pm 0.67^{\mathrm{pq}}$ & $82.11 \pm 0.26^{6} \quad 75.47 \pm 1.11^{g}$ \\
\hline & 62.5 & $21.98 \pm 0.50^{B}$ & $27.61 \pm 1.52^{\mathrm{A}}$ & $30.28 \pm 0.87^{\mathrm{yz}}$ & $31.22 \pm 1.15^{\mathrm{xyz}}$ & $29.75 \pm 0.85^{2}$ & $33.76 \pm 1.81^{v}$ & $31.81 \pm 1.05^{\mathrm{wxy}}$ & $32.65 \pm 0.34^{\mathrm{wwx}}$ & $33.36 \pm 0.56^{\mathrm{wW}}$ & $79.47 \pm 0.15^{\mathrm{f}} \quad 72.40 \pm 1.35^{\mathrm{h}}$ \\
\hline & 31.25 & $11.87 \pm 0.42^{\mathrm{F}}$ & $16.20 \pm 0.88^{\mathrm{E}}$ & $16.78 \pm 0.61^{\mathrm{E}}$ & $17.19 \pm 0.43^{\mathrm{DE}}$ & $17.26 \pm 0.46^{\mathrm{DE}}$ & $19.05 \pm 0.41^{\mathrm{CD}}$ & $17.90 \pm 0.96^{\mathrm{DE}}$ & $18.72 \pm 0.55^{\mathrm{CD}}$ & $20.41 \pm 0.32^{\mathrm{BC}}$ & $71.29 \pm 1.70^{\mathrm{h}} \quad 67.29 \pm 1.93^{\mathrm{jk}}$ \\
\hline \multirow{2}{*}{$\begin{array}{l}\text { Antioxidant } \\
\text { test }\end{array}$} & \multirow{2}{*}{$\begin{array}{c}\text { Treated } \\
\text { conc. } \\
(\mu \mathrm{g} / \mathrm{mL})\end{array}$} & \multicolumn{3}{|c|}{$20^{\circ} \mathrm{C}$} & \multicolumn{3}{|c|}{$25^{\circ} \mathrm{C}$} & \multicolumn{3}{|c|}{$30^{\circ} \mathrm{C}$} & Positive control \\
\hline & & 3 days & 5 days & 7 days & 3 days & 5 days & 7 days & 3 days & 5 days & 7 days & Trolox \\
\hline \multirow{6}{*}{ FRAP } & 1,000 & $34.35 \pm 0.46^{\mathrm{h}}$ & $38.29 \pm 0.98^{g}$ & $41.51 \pm 0.59^{\text {ef }}$ & $43.64 \pm 0.23^{d}$ & $42.33 \pm 0.92^{\text {de }}$ & $40.62 \pm 0.41^{\mathrm{f}}$ & $37.55 \pm 0.46^{g}$ & $31.60 \pm 1.13^{\mathrm{i}}$ & $28.81 \pm 0.93^{j}$ & $92.27 \pm 0.25^{\mathrm{a}}$ \\
\hline & 500 & $18.48 \pm 1.19^{\mathrm{m}}$ & $23.06 \pm 1.31^{1}$ & $24.35 \pm 0.32^{1}$ & $28.01 \pm 0.39^{\circ}$ & $23.00 \pm 0.79^{1}$ & $26.13 \pm 0.00^{k}$ & $23.36 \pm 0.25^{1}$ & $18.81 \pm 0.28^{\mathrm{m}}$ & $16.15 \pm 1.11^{\mathrm{n}}$ & $92.26 \pm 0.07^{\mathrm{a}}$ \\
\hline & 250 & $11.73 \pm 0.66^{\mathrm{q}}$ & $13.77 \pm 0.72^{\mathrm{op}}$ & $14.31 \pm 0.46^{\circ}$ & $16.66 \pm 0.67^{\mathrm{n}}$ & $12.30 \pm 0.32^{\mathrm{pqr}}$ & $15.72 \pm 0.30^{\mathrm{n}}$ & $13.04 \pm 0.32^{\mathrm{opq}}$ & $12.30 \pm 0.32^{\mathrm{par}}$ & $11.10 \pm 2.80^{5}$ & $92.66 \pm 0.07^{\mathrm{a}}$ \\
\hline & 125 & $6.39 \pm 0.56^{\mathrm{uv}}$ & $7.86 \pm 0.78^{t}$ & $8.68 \pm 0.47^{\text {st }}$ & $9.66 \pm 1.97^{\mathrm{s}}$ & $6.17 \pm 0.74^{\mathrm{uvw}}$ & $8.36 \pm 1.69^{\text {st }}$ & $7.24 \pm 0.65^{\mathrm{tu}}$ & $7.86 \pm 0.18^{t}$ & $5.30 \pm 1.15^{\mathrm{wwxy}}$ & $92.17 \pm 0.05^{\mathrm{a}}$ \\
\hline & 62.5 & $1.79 \pm 1.24^{\mathrm{DEF}}$ & $3.76 \pm 0.34^{\mathrm{ZAB}}$ & $4.65 \pm 0.84^{\mathrm{xy} A \mathrm{~A}}$ & $5.74 \pm 0.65^{\mathrm{vwx}}$ & $4.08 \pm 1.21^{\mathrm{y} A \mathrm{~B}}$ & $4.76 \pm 0.33^{\text {wxyz }}$ & $3.07 \pm 0.34^{A B C D}$ & $3.64 \pm 0.20^{\mathrm{zABC}}$ & $0.84 \pm 1.03^{\text {ef }}$ & $90.19 \pm 0.20^{b}$ \\
\hline & 31.25 & $1.43 \pm 1.09^{E F}$ & $3.28 \pm 1.57^{\mathrm{ZABCD}}$ & $2.96 \pm 0.53^{\mathrm{BCD}}$ & $3.41 \pm 0.91^{\mathrm{zABC}}$ & $2.15 \pm 0.53^{\mathrm{CDE}}$ & $3.18 \pm 0.72^{\mathrm{ZABCD}}$ & $2.96 \pm 0.53^{\mathrm{BCD}}$ & $3.64 \pm 0.39^{\mathrm{zABC}}$ & $0.49 \pm 0.21^{\mathrm{f}}$ & $81.13 \pm 0.10^{c}$ \\
\hline
\end{tabular}

${ }^{1)}$ Values represent the mean $\pm \mathrm{SD}(\mathrm{n}=3)$. Means with different superscript with the column are significantly different $(\mathrm{p}<0.05)$ by Duncan's multiple range test.

반면에 $25^{\circ} \mathrm{C}$ 와 $30^{\circ} \mathrm{C}$ 에서는 각각 $43.64 \pm 0.23,42.33 \pm 0.92$ 및 $40.62 \pm 0.41$ 과 $37.55 \pm 0.46,31.60 \pm 1.13$ 및 $28.81 \pm 0.93 \%$ 로 발 효기간에 따라 낮아지는 경향이었다. 따라서 $\mathrm{DPPH}$ 와 FRAP assay에 의한 막걸리 추출물의 항산화효과는 발효온 도에 따라 $25^{\circ} \mathrm{C}>20^{\circ} \mathrm{C}>30^{\circ} \mathrm{C}$ 의 순이었으며, ABTS assay에 의한 항산화효과는 온도에 관계없이 비교적 높은 활성을 나타내었다.

\section{a-Amylase 저해활성}

탄수화물의 소화는 주로 amylase group에 의해 이루어지 며, 그 중 a-amylase는 소장 상피세포의 brush membrane에 존재하는 효소로 탄수화물의 a-D-(1,4)-glucan 결합을 분해 하는 효소이다(20). 따라서 소장의 a-amylase를 저해함으로 써 포도당의 흡수를 억제시킬 수 있어 a-amylase의 저해활 성은 혈당수치 상승억제의 지표로 사용된다(21). 막걸리의 발효온도 및 발효기간(3, 5 및 7일)에 따른 a-amylase 저해활 성은 $1 \mathrm{mg} / \mathrm{mL}$ 처리하였을 때, $20^{\circ} \mathrm{C}$ 에서는 각각 $50.59 \pm 0.49$, $53.49 \pm 0.41$ 및 $58.00 \pm 0.64 \%, 25^{\circ} \mathrm{C}$ 에서는 각각 $54.25 \pm 0.77$, $60.45 \pm 0.25$ 및 $73.48 \pm 0.25 \%$ 이었으며, $30^{\circ} \mathrm{C}$ 에서는 각각 $67.99 \pm 0.11,73.64 \pm 0.43$ 및 $75.51 \pm 0.26 \%$ 로 비교적 높은 활
성을 나타내었으며, 발효온도와 기간에 비례하여 활성이 증가하는 경향이었다(Table 5). 이는 혈당강하제 의약품으 로 사용되고 있는 acarbose와 비교했을 때 상당히 높은 수준 으로 항당뇨 기능성 식음료로의 개발에 좋은 기초 자료가 될 것으로 기대된다. 막걸리의 항당뇨 활성에 대한 연구는 아직 미흡한 실정으로, 막걸리를 빚은 후 술을 걸러내는 과정에서 생성된 주박의 제 1 형 당뇨 쥐의 혈당강하 효과를 본 연구(41)만을 찾을 수 있었다.

\section{전지방세포 분화억제 효과}

항비만 활성은 세포에 염색된 Oil red O dye를 용해시켜 흡광도를 측정하여 3T3-L1 지방전구세포내 lipid droplet 형성의 억제정도로 측정하였다(Fig. $1, \mathrm{~A}$ ). 즉 $20^{\circ} \mathrm{C}$ 에서는 발효기간에 따라 지방세포로의 분화억제활성이 $22 \%$ 에서 $46 \%$ 로 증가하였다. 그러나 $25^{\circ} \mathrm{C}$ 에서는 발효 5일째에 $55 \%$ 까지 증가하였으나 7 일째에 $48 \%$ 로 약간 감소하였다. 한편 $30^{\circ} \mathrm{C}$ 에서 발효한 막걸리는 발효기간이 경과할수록 $38 \%$ 에 서 $50 \%$ 까지 억제활성이 증가되었다. Oil red O 염색에 대한 현미경적 관찰에서도 막걸리 추출물을 처리한 세포의 lipid droplet이 대조군에 비하여 작은 구의 형태로 형성되어 lipid 
Table 5. a-Amylase inhibition activity of Makgeolli during fermentation conditions

\begin{tabular}{|c|c|c|c|c|c|c|c|c|c|c|}
\hline \multirow{3}{*}{$\begin{array}{c}\text { Treated conc. } \\
\quad(\mu \mathrm{g} / \mathrm{mL})\end{array}$} & \multicolumn{10}{|c|}{ a-Amylase inhibition activity (\%) } \\
\hline & \multicolumn{3}{|c|}{$20^{\circ} \mathrm{C}$} & \multicolumn{3}{|c|}{$25^{\circ} \mathrm{C}$} & \multicolumn{3}{|c|}{$30^{\circ} \mathrm{C}$} & \multirow{2}{*}{ Acarbose } \\
\hline & 3 days & 5 days & 7 days & 3 days & 5 days & 7 days & 3 days & 5 days & 7 days & \\
\hline 1000 & $50.59 \pm 0.49^{\mathrm{k} 1)}$ & $53.49 \pm 0.41^{j}$ & $58.00 \pm 0.64^{\mathrm{g}}$ & $54.25 \pm 0.77^{\mathrm{ij}}$ & $60.45 \pm 0.25^{\mathrm{f}}$ & $73.48 \pm 0.25^{\mathrm{c}}$ & $67.99 \pm 0.11^{\mathrm{d}}$ & $73.64 \pm 0.43^{c}$ & $75.51 \pm 0.26^{b}$ & $85.21 \pm 0.11^{\mathrm{a}}$ \\
\hline 500 & $22.96 \pm 1.75^{y}$ & $39.97 \pm 0.41^{\mathrm{pqr}}$ & $41.44 \pm 0.57^{\circ}$ & $25.73 \pm 1.42^{\text {wx }}$ & $55.29 \pm 0.57^{\mathrm{hi}}$ & $58.65 \pm 0.61^{g}$ & $53.00 \pm 0.40^{j}$ & $58.88 \pm 0.57^{g}$ & $53.49 \pm 0.82^{j}$ & $85.46 \pm 0.25^{\mathrm{a}}$ \\
\hline 250 & $18.09 \pm 2.07^{\mathrm{A}}$ & $14.86 \pm 0.69^{\mathrm{B}}$ & $36.87 \pm 0.06^{\mathrm{t}}$ & $24.40 \pm 0.44^{x}$ & $45.56 \pm 1.08^{\mathrm{m}}$ & $47.65 \pm 0.72^{1}$ & $37.85 \pm 0.46^{\text {st }}$ & $43.53 \pm 0.34^{\mathrm{n}}$ & $45.49 \pm 0.20^{\mathrm{m}}$ & $85.21 \pm 0.11^{\mathrm{a}}$ \\
\hline 125 & $8.10 \pm 0.78^{\mathrm{D}}$ & $11.53 \pm 0.10^{\mathrm{C}}$ & $20.12 \pm 1.01^{z}$ & $20.02 \pm 0.15^{z}$ & $38.90 \pm 0.94^{\mathrm{qrs}}$ & $41.64 \pm 1.05^{\circ}$ & $28.22 \pm 0.20^{\mathrm{v}}$ & $40.04 \pm 0.52^{\mathrm{pq}}$ & $40.37 \pm 0.48^{o p}$ & $85.46 \pm 0.25^{\mathrm{a}}$ \\
\hline 62.5 & $7.90 \pm 2.05^{\mathrm{D}}$ & $8.46 \pm 0.76^{\mathrm{D}}$ & $13.62 \pm 0.83^{B}$ & $13.59 \pm 0.20^{\mathrm{B}}$ & $33.47 \pm 0.77^{\mathrm{u}}$ & $39.52 \pm 0.70^{\mathrm{par}}$ & $22.86 \pm 2.39^{y}$ & $26.49 \pm 0.63^{\mathrm{w}}$ & $38.57 \pm .10^{\mathrm{rs}}$ & $63.61 \pm 0.37^{\mathrm{e}}$ \\
\hline 31.25 & _) & $7.81 \pm 1.35^{\mathrm{D}}$ & $6.24 \pm 0.39^{\mathrm{E}}$ & $11.92 \pm 0.60^{\mathrm{C}}$ & $25.21 \pm 0.65^{\mathrm{wx}}$ & $24.56 \pm 0.69^{\mathrm{x}}$ & $14.34 \pm 1.04^{\mathrm{B}}$ & $22.60 \pm 0.45^{y}$ & $25.41 \pm .11^{\mathrm{wx}}$ & $55.94 \pm 0.37^{\mathrm{h}}$ \\
\hline
\end{tabular}

${ }^{1)}$ Values represent the mean $\pm \mathrm{SD}(\mathrm{n}=3)$. Means with different superscript with the column are significantly different $(\mathrm{p}<0.05)$ by Duncan's multiple range test.

${ }^{2)}$ Trace $<0.0002 \mathrm{mg} / \mathrm{mL}$.

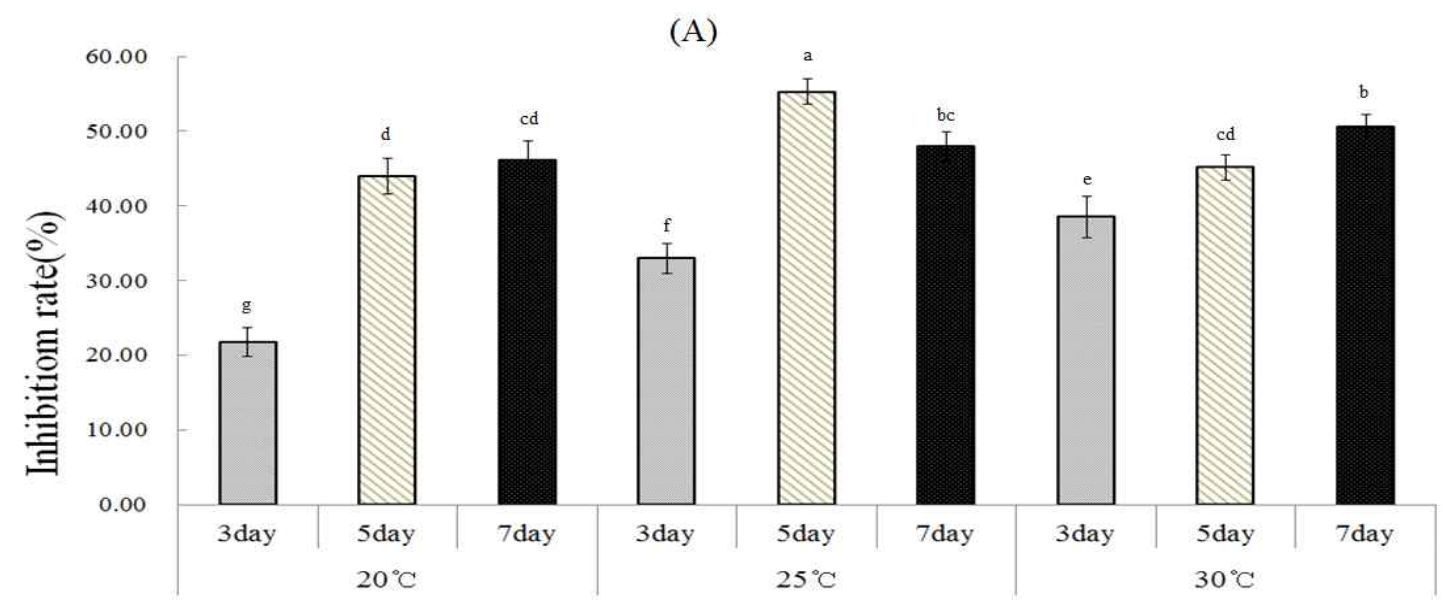

(B)

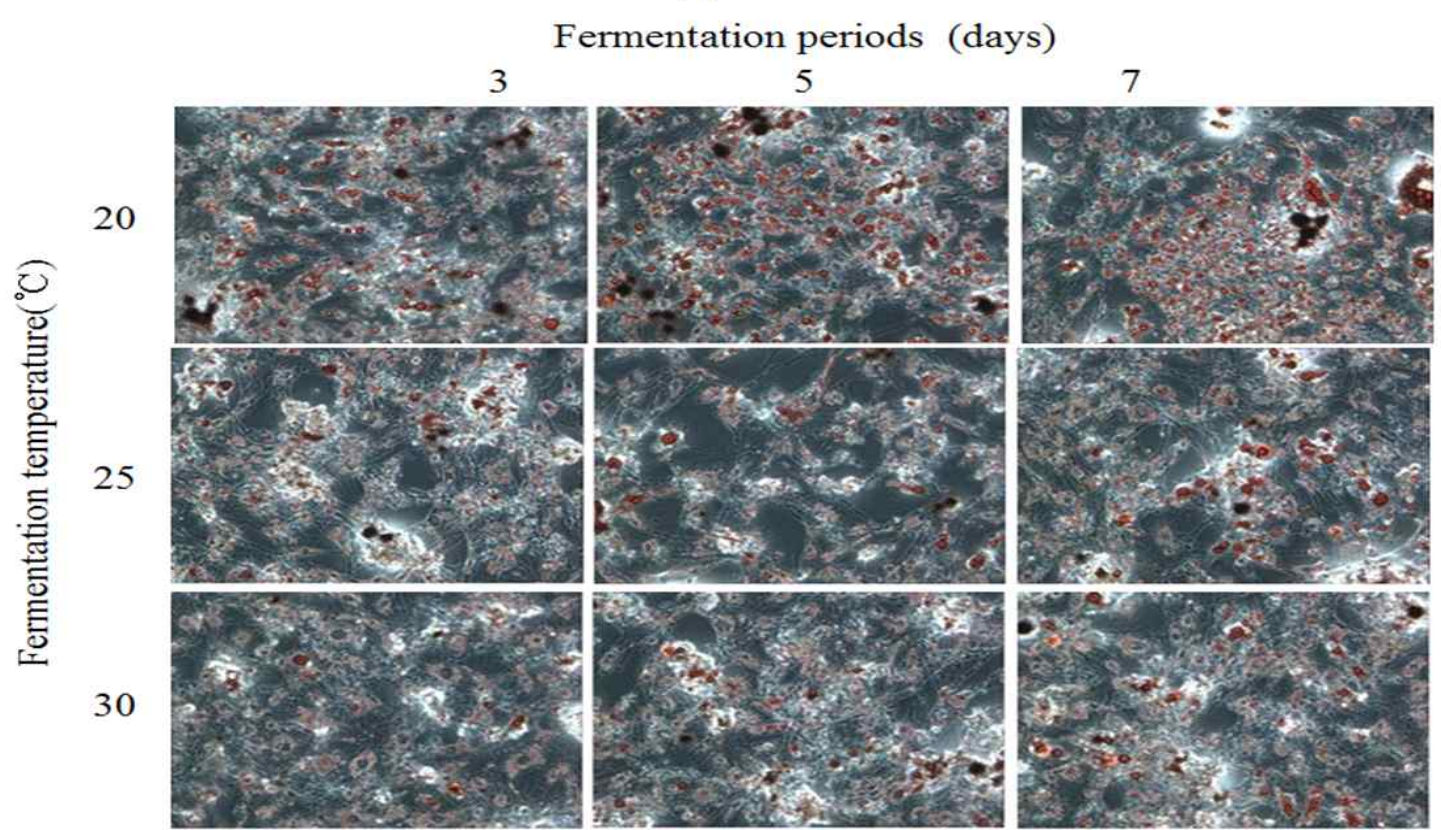

Fig. 1. (A) Inhibition rates of 3T3-L1 adipocyte cell differentiation of Makgeolli according to different fermentation conditions. (B) Comparisons of lipid accumulations in 3T3-L1 adipocyte cell of Makgeolli according to different fermentation conditions by oil red O staining.

Values represent the mean $\pm \mathrm{SD}(\mathrm{n}=3)$. Means with different superscript with the column are significantly different $(\mathrm{p}<0.05)$ by Duncan's multiple range test. 
accumulation이 감소한 것을 확인할 수 있었다(Fig. 1, B). 따라서 모든 막걸리 추출물에서 3T3-L1 지방전구세포의 분화유도과정을 억제시켰으며, 특히 $25^{\circ} \mathrm{C}$ 발효 5 일째에 가 장 억제율이 높다는 것을 알 수 있었다. 이는 시판 막걸리의 동결건조물의 처리가 미분화 상태 전구지방세포의 지방세 포로 분화에 미치는 영향을 평가한 결과, 모든 막걸리에서 지방세포 분화 저해활성을 나타내었다는 보고와도 일치한 다(42). 한편 누룩 농축물이 high-cholesterol diet-fed rat model에서 혈중 LDL-cholesterol과 total cholesterol을 낮추 는 효과를 관찰하였고, 비만세포의 활성화를 억제하는데 도움을 주는 PPAR-a 활성화와 아포지단백-A1의 분비를 촉진하는 기전으로 이루어진다고 보고된 바 있다(43). 막걸 리의 생리활성 효과는 DPPH radical 소거활성을 비롯한 항산화효과와 a-amylase 저해활성을 통해 알아본 항당뇨활 성, 3T3-L1 지방전구세포의 지방분화 저해율을 측정하여 지방축적 저해효과 등을 살펴보았을 때, 항산화효과는 근 소한 차이로 $25^{\circ} \mathrm{C}, 3$ 일차에 가장 활성이 높았으며, $\mathrm{a}$ -amylase 저해활성은 $25^{\circ} \mathrm{C}, 7$ 일차에, 지방분화 저해율은 2 $5^{\circ} \mathrm{C}, 5$ 일차에 가장 좋은 효과를 나타내었다. 따라서 $25^{\circ} \mathrm{C}$ 에 서 발효한 막걸리를 섭취하였을 때, 생리활성에 있어서 가 장 좋은 효과를 보일 것으로 판단된다.

\section{요 약}

건강음료로서 품질이 우수한 막걸리 제조를 위하여 발효 온도와 시간을 달리하여 제조한 막걸리의 품질특성과 biogenic amines(BAs)의 생성 및 생리활성을 비교 검토한 결과는 다음과 같다. 발효 중 $\mathrm{pH}$ 는 3.96 4.36이었으며, 총산 은 발효온도와 기간에 비례하여 증가하였다. 알코올 함유 량은 발효 5일째에 9.0 9.8\% 최대치를 보였으며, 총 페놀화 합물의 함량도 $25^{\circ} \mathrm{C}$, 발효 5 일째에 $3.01 \pm 0.07 \mathrm{mg} / \mathrm{g}$ 으로 가 장 높았다. 유기산의 함량은 주로 lactic acid이었으며, 온도 의 상승 및 발효기간에 비례하여 증가하였다. Biogenic amines(BAs)은 주로 tryptamine과 putrecine이었으며, tyramine은 발효 7 일째에 20,25 및 $30^{\circ} \mathrm{C}$ 에서 각각 6.91 과 11.70 및 $15.63 \mathrm{mg} / \mathrm{mL}$ 이 생성되었다. DPPH와 FRAP assay 에 의한 막걸리 추출물의 항산화효과는 $25^{\circ} \mathrm{C}>20^{\circ} \mathrm{C}>30^{\circ} \mathrm{C}$ 의 순이었으며, ABTS assay에 의한 항산화효과는 발효온도에 관계없이 $\mathrm{DPPH}$ 와 FRAP assay 보다 비교적 높은 활성을 나타내었다. a-Amylase 저해활성은 $1 \mathrm{mg} / \mathrm{mL}$ 처리하였을 때 $30^{\circ} \mathrm{C}$ 에서는 3,5 및 7 일차에 각각 $67.99 \pm 0.11,73.64 \pm 0.43$ 및 $75.51 \pm 0.26 \%$ 로 발효온도와 기간에 비례하여 활성이 증 가하는 경향이었다. 지방전구세포의 lipid droplet 형성 억제 활성은 $25^{\circ} \mathrm{C}$ 에서 5 일간 발효하였을 때, 활성이 가장 좋았다. 위와 같이 막걸리의 발효조건별 시험 결과로 볼 때, 막걸리 의 최적 발효조건은 $25^{\circ} \mathrm{C}$ 에서 5 일간 발효하였을 때 가장
품질이 우수한 막걸리를 제조할 수 있을 것으로 판단되 었다.

\section{Acknowledgement}

이 논문은 2014년도 경남과학기술대학교 기성회연구비 지원에 의하여 연구되었음.

\section{References}

1. An BH (1995) Study on problem of quality improvement of Korean traditional liquor. Bull Technol, 8, 130-137

2. Kang KE, Kim HK, Song KH, Lee HM (2012) Consumption pattern and strategies to increase popularity of Makoli according to age groups in men and women. Korean J Food Nutr, 25, 419-429

3. Shin MO, Kim MH, Bae SJ (2010) The effect of Makgeolli on blood flow, serum lipid improvement and inhibition of ACE in vitro. J Life Sci, 20, 710-716

4. Lee GH (1994) Characteristic and new technology of Korean Takju. Korean J Appl Microbial Biong, 7, 36-46

5. Ha JH, Shim YS, Cho YS, Seo DW, Jang HW, Jang HJ (2014) Analysis of E,E-farnesol and Squalene in Makgeolli using stir bar sorptive extration coupled wite gas chromatography-mass spectrometry. Korean J Anal Sci, 27, 60-65

6. Kim MH, Kim WH, Bae SJ (2001) The effect of Makkoli on serum lipid concentration in male rats. J Nat Sci Silla Univ, 9, 73-84

7. Wang SJ, Lee HJ, Cho JY, Park KH, Moon JH (2012) Isolation and identificatiom of antioxidants from Makgeolli. Korean J Food Sci Technol, 44, 14-20

8. Silla-Santos MH (1996) Biogenic amines; their importance in foods. Int J Food Microbiol, 29, 213-231

9. Kim SM, Han AR (2012) Storage properties and biogenic amines production of Makgeollis brewed with different proportions of rice and wheat flour. Korean J Food Sci Technol, 44, 583-591

10. Landete JM, Ferrer S, Polo L, Pardo I (2005) Biogenic amine in wines from three spanish region. J Agr Food Chem, 53, 1119-1124

11. Lee DP (2006) Policy Issues for the Globalization of Korean Traditional Liquer. Food Ind Nutr, 11, 1-9

12. Song JC, Park HJ, Shin WC (1997) Change of takiu qualities by addition of cyclodextrin during the brewing 
and aging. Korean J Food Sci Technol, 29, 895-900

13. NTSTSI (2005) Manufacturing guideline of Takju and Yakju. National Tax Service Technical Service Institute. Seoul, Korea, p 195-198

14. Folin O and Denis W (1912) On phosphotungstic phosphomolybdic compounds as color reagents. Journal of Biological Chemistry, 12, 239-249

15. Sung JM, Lim JH, Park KJ, Jeong JW (2008) Effects of semi-dried red pepper with a different seed ratio on the quality of kimchi. Korean J Food Preserv, 15, 427-436

16. Antolini F, Franciosini S, Floridi AL, Floridi A (1999) An ion pair HPLC method for the determination of histamine, tyramine, tryptamine, $\beta$-phenylethylamine and their amino acid precursors in cheese for industrial purposes. Italian Journal of Food Science, 11, 335-346

17. Heo JC, Lee DY, Son MS, Yun CY, Hwang JS, Kang SW, Kim TH, Lee SH (2008) Effects of Mole Crickets (Gryllotalpa orientalis) extracts on anti-oxidant and anti-inflammatory activities. J Life Sci, 18, 509-514

18. Re R, Pellegrini N, Proteggente A, Pannala A, Yang M, Rice-Evans C (1999) Antioxidant activity applying an improved ABTS radical cation decolorization assay. Radic Biol Med, 26, 1231-1237

19. Benzie IF, Strain JJ (1996) The ferric reducing ability of plasma (FRAP) as a measure of "antioxidant power": The FRAP assay. Anal Biochem, 239, 70-76

20. Lee BB, Park SR, Han CS, Han DY, Park E, Park HS, Lee SC (2008) Antioxidant activity and inhibition activity against a-amylase and a-glucosidase of Viola mandshurica extracts. J Korean Soc Food Sci Nutr, 37, 405-409

21. Oh SJ, Hong SS, Kim YH, Koh SC (2008) Screening of biological activities in fern plants native to Jeju island. Korean J Plant Res, 21, 12-18

22. Gao H, Kawabata J (2005) a-Glucosidase inhibition of 6-hydroxyflavones. Part 3: Synthesis and evaluation of 2,3,4 - trihydroxybenzoyl-containingflavonoid analogs and 6-aminoflavones as a-glucosidase inbibitors. Bioorg Med Chem, 13, 1661-1671

23. Sargent JM, Taylor CG (1989) Appraisal of the MTT assay as a rapid test of chemosensitivity in acute myeloid leukaemia. Br J Cancer, 60, 206-210

24. Green H, Kehinde O (1975) An established preadipose cell line and its differentiation in culture. П. Factors affecting the adipose conversion. Cell, 5, 19-27

25. Jo DH, Chung HJ, Cho HY, Lim ST (2011) Health function and utilization products of germinated brown rice. Food Sci Ind, 44, 76-86

26. So MH, Lee YS, Noh WS (1999) Improvement in the quality of Takju by a modified Nuruk Korean J Food Nutr, 12, 427-432

27. Jin TY, Chung HJ, Eun JB (2000) The effect of fermentation temperature on the quality of jinyangju, a Korean traditional rice wine. Korean J Food Sci Technol, 38, 414-418

28. Jin TY, Kim ES, Eun JB, Wang SJ, Wang MH (2007) Changes in physicochemical and sensory characteristics of rice wine, Yakju, prepared with different amount of red yeast rice. Korean J Food Sci Technol, 39, 309-314

29. Cai Y, Luo Q, Sun M, Corke H (2004) Antioxidant activity and phenolic compounds of 112 traditional Chinese medicinal plants associated with anticancer. Life Sci, 74, 2157-2184

30. Bubak HN, Guzel-Seydim ZB (2010) Antioxidant activity and phenolic content of wine vinegars produced by two different techniques. J Sci Food Agr, 90, 2021-2026

31. Choi SH, Kim OK, Lee MW (1992) A study on the gas chromatographic analysis of alcohols and organic acids during Takju fermentation. Korean J Food Sci Technol, 24, 272-278

32. Huh CK, Lee JW, Kim YD (2013) Comparison of organic acids, fusel oil contents and antioxidant activities of Yakju with the additions of various rice cultivars. Korean J Food Preserv, 20, 365-371

33. Jeong ST, Kwak HJ, Kim SM (2013) Quality characteristic and biogenic amine production of Makgeolli brewed with commercial Nuruks. Korean J Food Sci Technol, 45, 727-734

34. Forsythe WI, Redmond A (1974) Two controlled trial of tyramine in children with migraine. Dev Med Child Neurol, 16, 794-799

35. Ogawa H, Tsuji H, Seto A, Hara S, Totani Y (1996) Synergistic effect of spermine on antioxidation of polyunsaturated oil. J Japan Oil Chem Soc, 45, 1327-1332

36. Molyneux P (2004) The use of the stable free radical diphenylpicrylhydrazyl (DPPH) for estimating antioxidant activity. Songklanakarin J Sci Technol, 26, 211-219

37. Blois MS (1954) Antioxidant determination by the of a stable free radical. Nature, 26, 1199-1204

38. Jeong CH, Choi GN, Kwak JH, Kim JH, Choi SG, Shim $\mathrm{KH}$, Heo HJ (2010) In vitro antioxidant activities of cocoa phenolics. Korean J Food Preserv, 17, 100-106

39. Yu L, Haley S, Perret J, Harris M, Wilson J, Qian M 
(2002) Free radical scavenging properties of wheat extracts. J Agric Food Chem, 50, 1619-1624

40. Kwak JH, Choi GN, Park JH, Kim JH, Jeong HR, Jeong $\mathrm{CH}$, Heo HJ (2010) Antioxidant and neuronal cell protective effect of purple sweet potato extract. J Agric Life Sci, 44, 57-66

41. Kim SM, Cho WK (2006) Effects of Takju (Korean turbid rice wine) less on the serum glucose levels in Streptozotocin- induced diabetic rats. Korean J Food
Culture, 21, 638-643

42. Lee SJ, Kim JH, Jung YW, Park SY, Shin WC, Park CS, Hong SY, Kim GW (2011) Composition of organic acids and physiological functionality of commercial Makgeolli. Korean J Food Sci Technol, 43, 206-212

43. Lee SJ, Kim GW (2010) Hypolipidemic effect of hexane fraction from Rhizopus oryzae KSD-815 through peroxisome proliferator-activated receptor- $a$. J Korean Soc Appl Biol Chem, 53, 761-765 